\title{
Conservationists under fire in the Philippines
}

Regina Wegner and Quirin Schiermeier

The discovery last year of a new species of two-metre-long lizard focused zoologists' attention on the Visayan Islands in the Philippines, one of the world's biodiversity 'hotspots'. But German and Philippine scientists leading attempts to preserve the rich fauna and flora of this archipelago are facing a campaign of intimidation that they fear will erupt into violence.

Since 1995, the Philippine Endemic Species Conservation Project (PESCP), which is funded by the Frankfurt Zoological Society, has operated a conservation and agroforestry station in the northwest of the island of Panay, some 300 kilometres south of Manila.

The project team is involved in antihunting and anti-logging campaigns, and educates local communities in alternative, forest-friendly livelihoods, such as the cultivation of tiger grass, chicken breeding and banana production.

The team's scientific fieldwork includes the release and monitoring of endangered species, such as the Philippine spotted deer (Cervus alfredi), the Visayan warty pig (Sus cebifrons) and various species of hornbill. Last year, PESCP researchers discovered an arboreal monitor lizard, which they named Varanus mabitang. Five new frogs, four snakes and another, smaller lizard species have also been found in recent years.

Recently, however, PESCP members have been exposed to intimidation. "We found cartridge cases and shot hornbills planted in front of the station," says Eberhard Curio, a conservation biologist from the Ruhr University Bochum, who leads the project. "We know that we have enemies among some local families who tried, unsuccessfully, to smuggle poachers into the team. Moreover, some people are suspicious of our campaigns against logging and hunting."

The PESCP team has not yet been attacked, but Curio says the situation on adjacent islands is a cause for serious concern, with scientists having to trek daily to their research sites from secure lodgings.

"On Negros, for example, it has become too dangerous to spend the night in the forests," says Curio. In February, one forest ranger told a local newspaper: "We fled for our lives when we were being attacked by some 100 heavily armed men."

Nonetheless, Curio, who last year was appointed to the first European Union chair for biodiversity in Southeast Asia, will return to the Philippines in August to conduct a radio-telemetry study on released hornbills.

Despite local tensions, biodiversity and conservation programmes in the Philippines are generally well supported by the

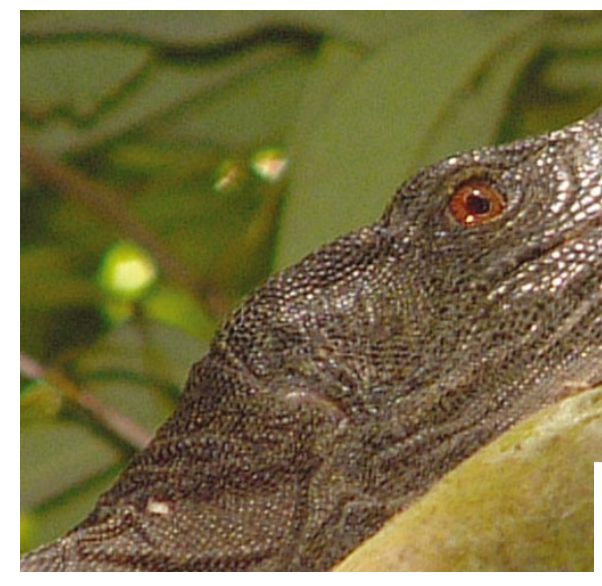

national and provincial governments. A dedicated biodiversity research unit has also been established at the University of the Philippines Los Baños. "These are very positive signals," says Flint Hobart, who oversees Philippine projects for Conservation International, a Washington-based non-governmental organization.

The Philippines is one of the world's hottest biodiversity hotspots (see Nature 403, 853-858; 2000). But it is also the one with the least remaining primary vegetation: only $3 \%$ of the original extent is left. The remaining rainforests continue to suffer from illegal logging.
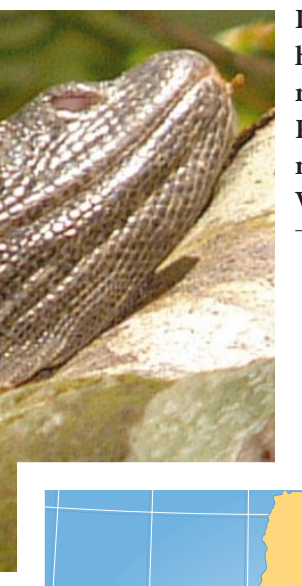

Looking up: researchers have discovered several new species in the Philippines, including a monitor lizard (left) in the Visayan Islands.

\section{Bush rallies opposition to cloning}

Erika Check, Washington

With a vote in the US Senate on banning therapeutic cloning just weeks away, anticloning politicians - including President George W. Bush - stepped up their rhetoric last week.

On 10 April, Senator Sam Brownback (Republican, Kansas), who is sponsoring a bill that would outlaw human cloning for any purpose, held a rally for supporters of his legislation. Later that day, many of those supporters moved to the East Room of the White House, where Bush called on the Senate to pass Brownback's bill. The issue is now expected to come to a vote before the end of May.

"Research cloning would contradict the most fundamental principle of medical ethics - that no human life should be exploited or extinguished for the benefit of another," Bush said, to enthusiastic applause.

After Bush's speech, Brownback told reporters that at least 40 senators supported his legislation - 11 votes shy of a majority. However, he added that he was confident of winning support from enough currently undecided senators to carry the vote.

Supporters of research cloning remain unfazed. "Vote counts differ on this issue," says Kevin Wilson, a spokesman for the Coalition for the Advancement of Medical Research.

But Brownback's opponents were spurred into action by last week's developments. After Bush's statement, senators who support the creation of cloned embryos to provide embryonic stem cells for use in regenerative medicine said they would merge two similar bills, both of which would allow research into therapeutic cloning but not cloning for reproduction.

On the day of Bush's speech, 40 Nobel laureates issued a statement opposing Brownback's bill, saying it would have a "chilling effect" on US science. "Such legal restrictions on scientific investigation would ... send a strong signal to the next generation of researchers that unfettered and responsible scientific investigation is not welcome in the United States," the statement declared. 